\title{
Pig wrestling: Chasing tales of modern swine production systems
}

P I G I A I S AN OMNIVORE'S QUEST for SUSTAINABLE MEAT BAR Y E 8 TABR०OK

Review by Robert Perry*

University of Kentucky

Review of Pig Tales: An Omnivore's Quest for Sustainable Meat, by Barry Estabrook. (2015). Published by W. W. Norton \& Co.; 336 pages; available as hardcover, paperback, ebook, and audiobook. Publisher's website: http://books.wwnorton.com/books/Pig-Tales/

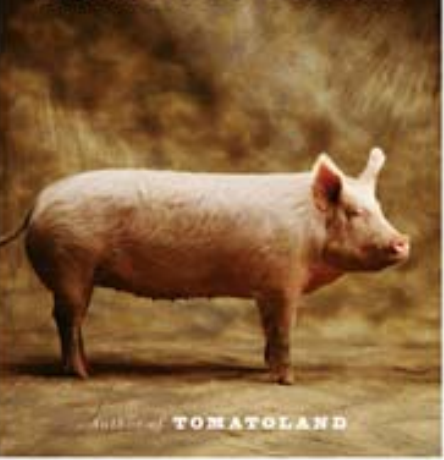

Submitted September 23, 2016 / Published online December 4, 2016

Citation: Perry, R. (2016). Pig wrestling: Chasing tales of modern swine production systems [Book review]. Journal of Agriculture, Food Systems, and Community Development, 7(1), 137-138. http://dx.doi.org/10.5304/jafscd.2016.071.009

Copyright (C) 2016 by New Leaf Associates, Inc.

$\mathrm{N}^{\circ}$ o matter the subject, Barry Estabrook is a writer whose experiences in the world of food and agriculture are wide and deep. Pig Tales: An Omnivore's Quest for Sustainable Meat is no exception. The title gives his approach away: this is a collection of tales from his travels and interviews to understand pig nature and production. He continually engages the reader by supplying deep backstories for his most significant interviewees. It is obvious he connects personally with each one, is

\footnotetext{
* Bob Perry teaches, researches, and cooks as the Chef in Residence in the Department of Dietetics and Human Nutrition at the University of Kentucky. His last research project calculated carcass yields for eight heritage breeds of pigs, and his current research is focused on adding value to ubatuba peppers by making paprika and other products. He can be contacted at rrperr2@uky.edu.
}

able to put them at ease and thus get at the truth of their situations.

Pig Tales begins with a scene of courtroom drama in which Estabrook almost gets arrested for being himself attending a trial in in which neighbors maintain that the concentrated animal feeding operation (CAFO) built nearby emits such foul odors they cannot be outside on their own property. The judge in the case is leery of his presence because of his previous book, Tomatoland, and so has him removed-an action that propels Barry on his journey.

His quest begins as he examines research into pig intelligence. Though he doesn't anthropomorphize them, he explores their innate intelligence through the lens of academic research, on-farm experiences, and their being kept as pets. For the remainder of the book he subdivides pigs into 
three major groups and examines each separately based on the lives they lead-feral, confined, and pastured-a strategy that works brilliantly.

First, through informative and amusing interviews, and aided by tales from his own travels, Estabrook endeavors to understand feral pigs and the havoc they can create. From humid southern swamps to a frozen Saskatchewan to the wide expanse of Texas, he explores how feral pigs have outsmarted all those who have tried to eradicate them. He learns that no matter the climate or terrain, feral pigs make their environment their own despite all human attempts to manage them.

Next, Estabrook explores confinement hog operations in a much longer section. His first tale makes the reader contemplate whether the operation he describes is actually viable. It is owned and operated strictly in accordance with the latest research by a veterinarian who has been witness and participant to the evolution of pig farming from outdoor to indoor. But, while the story starts brightly, it ends where all CAFO tales do: in the mire where manure is a problem rather than a resource. Estabrook's interviews with former employees of large confinement operations describe what has often been said before about such operations. Premium Standard in northern Missouri (now owned by the Chinese corporation that bought Smithfield) is one such example as a vertically integrated operation that both raises and processes pigs and whose tale mirrors the processing horrors portrayed in Fast Food Nation by Eric Schlosser.

Estabrook's account of Murphy Family Farms in North Carolina illustrates the extent to which scale matters. Going beyond human scale to an industrial corporate scale can be the downfall of some operations. Farmer Wendell Murphy wanted to help other farmers, and so he began to increase the scale of his operation and others' to be more profitable. He did this by organizing them and starting new businesses to provide both feeder pigs and feed. But, as Estabrook illustrates in the Murphy case, when one ignores environmental and human consequences for the sake of profit, the available political money and power become blind. Estabrook uses this example to compare the actions of Big Pork addressing challenges to its operations to those of Big Tobacco during its downfall.

The chapter titled "Drug Abuse" includes Estabrook's description of the pork industry in Denmark. While CAFOs are also utilized there, the conditions of Danish industrial pork operations stand in stark contrast with those he describes in the U.S. This was well illustrated by his account of being welcomed to a slaughterhouse outside Copenhagen, unlike slaughter operations in the U.S. that refused him tours or did not respond to his requests. He describes the Danish operation as immaculately clean with numerous robots performing work that would otherwise take many human hands. Another aspect of scale is well illustrated here in his description of where each part of the pig goes. It is only at a large scale that the viscera become an asset rather than waste; what parts go to which countries may give readers pause if they are world travelers.

In the last section of the book, "When Pigs Fly," Estabrook takes readers on a tour of pastured operations of varying sizes, but all with the same lofty and delicious goals. The names in this section -Kremer, Willis, Small, and Yezzi-are recognizable to those pursuing better pork, making it a satisfying end to the book. Both Kremer and Willis have lifelong experiences with pigs, from pastured to CAFO and back again. These were some of the first operations to turn their backs on the industrialization of pork and, in the cases of Small and Yezzi, to start from scratch without any prior experience-something with which many new farmers could identify.

Pig Tales is like a great lecture from a favorite professor; Estabrook weaves hard facts and his experiences together into compelling tales that both entertain and educate the reader and lets them draw their own conclusions about the different systems. This is not a scientific or political treatise, but reliable first-hand information on the state of pigs today. 